\title{
OSMANLI HALKLARININ MEHDÎLİK ALGISI VE MÜSLÜMAN TEBAA TARAFINDAN BU ALANDA YAZILAN ESERLER BAĞLAMINDA KURTARICI BEKLENTISINIIN SOSYO-POLITIK BAĞLANTILARI
}

Mahmut ÇINAR

Doç. Dr., Gaziantep Ü. İlahiyat Fakültesi cinarmahmut02@gmail.com

\section{Öz}

Altı yüzyıl gibi hükümranlık süresi, uzun bir zaman dilimine yayılan Osmanlılar dönemi, Mehdîlik literatürü alanında çok da zengin değildir. Bu durumun Mehdîlik konusunun sosyopsikolojik ve sosyo-politik bağlantılarıyla doğrudan alâkalı olduğu düşünülmektedir. Bununla beraber, hem var olan bilgileri nakletme hem de yeniden telif etme yöntemiyle bu alanda bir kısım çalışmaların kaleme alındığında da kuşku yoktur. Özellikle Osmanlıların Duraklama Dönemi sonrası ve XX. yüzyılda dağılma sürecine girmesiyle, bu konu sâir zamanlara göre daha çok önem kazanmıştır. Bu makalemizde Osmanlılar döneminde Mehdîlik ve kurtarıcı inancı konusunda yazılan eserlerden örnekler alınacak, bunlar arasından duraklama ve dağılma dönemlerinde yazılanlarından öne çıkanlar örnek alınarak değerlendirilecektir. Çalışmamızda Osmanlı halklarından İslâm dışındaki çeşitli din ve inanç mensuplarının "kurtarıcı beklentisi" etrafındaki çabaları dışarıda tutularak, sadece Müslüman tebaanın Mehdîlik konusunda kaleme aldığı literatür bağlamında tespitler yapılmaya çalışılacaktır.

Anahtar Kelimler: Mehdîlik Literatürü; Kurtarıcı İnancı; Osmanlılar; Kurtuluş Teorileri; Osmanlı Tarihi; Yazma Eserler.

\section{OTTOMANS' UNDERSTANDING OF MAHDI AND SOCIO-POLITICAL ROOTS OF MAHDI'S EXPECTATION IN THE CONTEXT OF THE BOOKS OF MUSLIMS IN OTTOMANS}

\begin{abstract}
The Ottomans whose long reigning period spread over six centuries is not rich in terms of Mahdi literature. It is considered that this situation is directly related to the socio-psychological sides of the issue. However, it is unquestionable that there were some works which conveyed the pre-existing information about Mahdi belief. Especially after the period of stagnation and collapse in early $X^{\text {th }}$ century, this issue became more important than other times. In this article, the works related to the belief of Mahdi in the Ottoman times are going to be identified and some examples taken from the periods of establishment, stagnation and collapse to be assessed. In this study, we are only going to deal with Muslims' Mahdi beliefs and other religions expectations of redeemer among the Ottomans are not going to be taken into consideration.
\end{abstract}

Keywords: Mahdi Literature; Belief in Redeemer; Ottomans; Salvation Theories; Ottoman History; Manuscripts. 


\section{Giriş}

Osmanlılar döneminde, Mehdîlik konusu etrafında yazılan birçok risâle bulunmaktadır. Bu risâleler, oldukça kısa ve çoğu zaman başka eserlerin bir parçası olarak kaleme alınmışlardır. Ayrıca bunların önemli bir kısmı, daha önce başkaları tarafından kaleme alınan risâlelerin bir tekrarı, şerhi ya da hâşiyesi konumundadır. Bununla beraber çok nâdir de olsa, Mehdîlik etrafında orijinal birtakım düşüncelerin ortaya konulduğu da görülmektedir. Osmanlılar döneminde yaygın olan dinî-fikrî eğilim, Felsefe, Kelâm ve Tasavvufun her üçünün de etkisinde şekillenmekle beraber, Tasavvufun etkisi, daha çok ön plana çıkmaktadır. Buna bağlı olarak tasavvuf düşüncesi ile arasında doğrudan bir ilişki bulunan Mehdîlik konusu da bu çerçevede varlığını sürdürmüştür. Söz konusu çevreler tarafından, bu alanda kaleme alınan risâleler tekrar edilmiş, kimi zaman bir kısım açıklayıcı ilâvelerde bulunmakla yetinilmiştir.

Çalışmamızda zaman zaman farklı coğrafyalara işaret edilmekle beraber, daha çok merkez coğrafya olarak değerlendirilen ve Bâb-1 Âlî’yi çevreleyen Anadolu ve çevresindeki coğrafya öne çıkarılmıştır. Kuşkusuz bu coğrafyada da farklı din ve inanç mensupları bulunmakta ve bunların da kendi aralarında zaman zaman kurtarıcı beklentisi içerisine girdikleri bilinmektedir. Ancak söz konusu arayışlar konumuzun dışında tutulmuştur. Osmanlılar'ın yurt edinerek muhtelif coğrafyalara yayıldıkları aslî yurtları olan Anadolu topraklarında, Mehdîlik düşüncesinin bu yörenin sâkinleri arasında daha belirgin bir fikir, düşünce ve en önemlisi kurtuluş beklentisi haline gelip gelmemesi ile bu alanda yazılı metinlerin oluşturulması arasında doğrudan bir ilişki bulunmaktadır. Zira Mehdîlik inancı ve mehdî beklentisi, daha çok insanların önemli ölçüde karşı karşıya kaldıkları kriz dönemlerinde güçlenmekte ve bu inancı paylaşan çevreler çeşitli arayışlara girmektedir. Gerçekten de gerek Müslümanlar arasında gerek diğer inanç çevreleri arasında, kurtarıcı beklentisi ile yaşanılan acılar arasında doğrudan bir paralellik görmek mümkündür. ${ }^{1}$ Bu durumu görebilmek için Mecûsilik, Yahudilik ve Hıristiyanlık gibi dinler ile başta Şîa olmak üzere, İslâm tarihinde Mehdîlik düşüncesine daha sıkı bir şekilde sahip çıkan çevreler önem arz etmektedir. Bu çevrelerin söz konusu düşüncenin teorik arka planını oluşturdukları ilgili dönemlere bakmak yeterli olacaktır. Bu çerçeveden bakıldığında, Müslümanlar arasında Mehdîlik düşüncesinin ortaya çıkarak, daha sonraları önemli ölçüde taraftar bulmasını, Hz. Hüseyin'in Kerbelâ'da şehid edilmesinden bağımsız olarak düşünmemiz, hiç de kolay değildir.

Mehdîlik ve benzeri diğer kurtuluş hareketleri ile bunların ortaya çıkmasına neden olan sosyal ve siyasal ortam hakkında geniş bilgi için bkz. Mahmut Çınar, Tarihte ve Günümüzde Mehdîlik, (İstanbul: Rağbet Yayınları, 2013), s. 29-47.

\begin{tabular}{|c|c|c|}
\hline 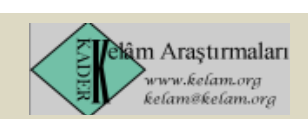 & $\begin{array}{l}\text { Kelâm Araştırmaları Dergisi } \\
\text { Journal of Kalâm Researches } \\
\text { [KADER-e-ISSN: 1309-2030] }\end{array}$ & 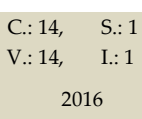 \\
\hline
\end{tabular}


Mehdîliğin târihî-sosyolojik bağlantıları dikkate alındığında, Osmanlılar döneminde oldukça uzun olan târihî seyrine rağmen, Mehdîlik hakkında çok fazla fikir üretilmemiş olmasını ve eser yazılmamasını anlamak zor değildir. Zira zaferden zafere, fetihten fetihe koşan bir toplum için, kurtarıcı beklentisi mâkûl bir duruş değildir. Güçlü bir padişahın payitahtta bulunması, farklı lider arayışlarına ihtiyaç bırakmamıştır. Fatih Sultan Mehmed, Yavuz Sultan Selim ve Kanûnî Sultan Süleyman gibi padişahların hükümrânlıkları altında, kurtarıcı olarak ortaya çıkacak birisinin, Müslüman topluma vadedebileceği çok fazla bir şey yoktu. Bununla beraber, Osmanlılar dönemi olarak değerlendirebileceğimiz XIII-XX. asırlarda, Anadolu'da kriz dönemleri şeklinde nitelendirebileceğimiz belirli dönemlerin yaşandığı kuşkusuzdur. Bu dönemleri: 1. XIII-XIV. yüz yıl; 2. XVII. yüz yıl ile 3. Osmanlı Devleti'nin yıkılışına sahne olan XX. yüzyılın başları şeklinde özetlemek ve örneklendirmek mümkündür. Gerçekten de bu yüzyıllarda Mehdîlik çerçevesinde değerlendirebileceğimiz önemli eserlerin kaleme alındığı görülmektedir. Bunun sebebi, her üç dönemde de yaşanılan siyasî zaaf ve boşluktur. Söz gelimi: 1. Dönemi kapsayan XIII-XIV. yüzyıllarda henüz Osmanlı Devleti'nin tam olarak kuruluş aşamasını tamamlayamamış olmasından kaynaklanan siyasî bir boşluk yaşanmaktadır. 2. Dönem: Literatürde XVII. yüzyıl krizi olarak tartışılan bu dönemde ise, dirâyetsiz olan padişahların önceki yüzyılda olduğu gibi güçlü kişilikler olmaması ve tahtlarından zorla indirilmeleri gibi sebepler yüzünden güçlü lider arayışları başlamıştır. 3. Dönemi içine alan XX. yüzyılda ise Osmanlı Devleti'nin yıkılma tehlikesi ile karşı karşıya kalması ve sonunda da dönemin siyasî buhrân ve savrulmalarına dayanamayarak tarihe karışması karşısında Anadolu insanının gelecek endişesi artmıştır. Beklenen kurtarıcı ve Mehdîlik hakkındaki bu görüntü, psiko-sosyolojik bir fenomen olması bakımından, Osmanlı dönemi Mehdîlik literatürünün bu kavram bağlamında örnekleriyle incelenerek bu durumun tespit edilmesi önem arz etmektedir.

Bu çalışmamızda Osmanlılar döneminde Mehdîlik etrafında kaleme alınan literatüre zaman zaman farklı örnekler vererek değinmekle beraber, yukarıda sıraladığımız her üç dönemin bir fotoğrafını yansıtma özelliğine sahip olan literatür üzerinde durulacaktır. Böylelikle dönemin zihin dünyası ve Mehdîlik karşısındaki tavırları deşifre edilmeye çalışılacaktır. Şunu hemen belirtmek gerekir ki, özellikle yaşadığımız dönem olmak üzere, ümmetin buhrân zamanlarında, bu alanda daha çok kitap ve risâle kaleme alınmıştır. Osmanlılar'ın kuruluş ve yükseliş döneminin bu anlamda zengin olmadığını, özellikle belirtmemiz gerekir.

Bununla beraber, başta Celâleddîn es-Süyûtî (ö. 911/1505)² ve Aliyyü'l-Kârî (ö. 1014/1606) gibi, İslâm düşünce târihînde yazdıkları eserlerin sayısı

Bilindiği gibi Süyûtî Osmanlılar'ın Mısır'1 fethetmelerinden kısa bir süre önce vefat etmiştir. Kendisinin yaşadığı dönemde Mısır, Osmanlı coğrafyasının asli bir parçası

$\begin{array}{ccc}\text { Kelâm Araştırmaları Dergisi } & \text { C.: 14, } & \text { S.: } 1 \\ \text { Journal of Kalâm Researches } & \text { V.: 14, } & \text { I.: } 1 \\ \text { [KADER-e-ISSN: 1309-2030] } & 2016\end{array}$


dikkate alındığında, profili yüksek olan bu ve benzeri şahsiyetler tarafından, çeşitli eserler kaleme alınmıştır. Gerçekten de Osmanlı coğrafyasının taşra bölgelerinde yaşayan ulemânın bu alanda hiç de azımsanmayacak derecede eser kaleme aldıklarını kaydetmek gerekir. $\mathrm{Bu}$ müelliflerin büyük çoğunluğu, konuyu daha çok rivâyetler etrafında nakletmekle yetinmekle beraber, İmâm Şa'rânî (ö. 973/1565) gibi ilmî kişiliği yanında tasavvufî ve sosyal ilişkileri açısından da dönemin önemli şahsiyetleri arasında sayılan kimseler de, bu konudaki düşünce ve değerlendirmelerini özgün bir şekilde kaleme almışlardır. Bu anlamda konuyla ilgili mülâhazaların müstakil eserler kadar, farklı eserlerin içinde bölüm ya da fasıl olarak yer aldığını da belirtmek gerekmektedir. Bu tür değerlendirmelerin yer aldığı eserlere örnek olarak İmâm Şa'rânî'nin akâid konularına tahsis ettiği el-Yevâkît ve'lcevâhir fì beyâni akâidi'l-ekâbir'ini verebiliriz. Şa'rânî bu eserinin "Şârî'in kıyâmetin alâmetleri olarak haber verdiklerinin tümünün hak olduğu hakkındadır" başlığını taşıyan altmış beşinci mebhasini, kıyâmet alâmetlerine ayırmaktadır. ${ }^{3} \mathrm{O}$, söz konusu alâmetleri, literatürde çok fazla alışık olmadığımız bir sıralama ile vermekte ve bunların sayımını mehdînin zuhûrundan başlayarak aktarmaktadır. Buna göre kıyâmete bir tek gün bile kalsa, Allah o günü uzatacak ve mehdî zuhûr edecektir. Mehdî, Hasan elAskerî'nin (ö. 260/874) oğlu Muhammed b. Hasan b. Ali b. Muhammed'dir" Şiî literatürün tasvîr ettiği gibi, bu zât 15 Şâban 255 (29 Temmuz 869) tarihinde doğdu ve günümüze kadar hayatta olup Hz. İsâ ile buluşuncaya kadar ölmeyecektir. Şa'rânî, Mehdî'nin hükümrânlık süresi ile ilgili olarak yedi ve dokuz gibi ifadeleri kullanmakla beraber, bunun: "Şüphesiz

olmamakla beraber, onun eserlerinin etkisi ve Misır'ın âdetâ bir daha kopmayacak şekilde Osmanlı topraklarına ilhâkından dolayı bu değerlendirmeye konu olmuştur.

3 Abdülvehhâb eş-Şa'rânî, el-Yevâkît ve'l-cevâhir fî beyâni akâidi'l-ekâbir, (Beyrut: 2003), s. 405-411.

Şa'rânî, Mehdî konusunda genel olarak İbnü'l-Arabî'nin (ö. 638/1240) görüşlerini paylaştığı halde, onun Hz. Hasan'ın soyundan olduğu görüşüne katılmamaktadır. “Hasan b. Ali'nin oğludur" ifadesi, her ikisinin eserlerinde de geçmektedir. Ancak Şa'rânî, Hz. Hüseyin'e kadar bütün dedelerini sayarak bunun İmâmiyye Şîa'sının "elKâim" olarak niteledikleri on ikinci imâm olduğunu ifade etmektedir. Buna karşlık İbnü'l-Arabî, "Hasan b. Ali b. Ebû Talib'in evlâdındandır" demek sûretiyle Hz. Hasan'1 ön plana çıkarmaktadır. İbnü'l-Arabî'nin ifadesindeki "b. Ebû Talib" ibaresini saymazsak, diğer kısmını telif etmek mümkündür. Şayet bu kısım el-Fütûhât'ın nüsha farklarından kaynaklanmıyorsa, Şa'rânî'nin, Mehdî'nin soyu konusunda İbnü'lArabî’den farklı düşündüğü görülmektedir. Ancak kütüphanelerimizin büyük çoğunluğunda bulunan el-Fütûhât'ın nüshalarıyla Şa'rânî'nin el-Yevâkit'te referans verdiği nüshalar arasında sınırlı da olsa bir kısım farklılıkların olduğu bilinmektedir. Büyük bir ihtimalle söz konusu görüş ayrılı̆̆ının kaynağı da bu olsa gerektir. Gerçekten de Fütûhât'ın bir kısım baskılarında Mehdî tasvir edilirken söz konusu ifade: "Hz. Peygamber'in ailesinden Fatıma'nın evladından, ismi Hz. Peygamber'in ismine uygun ve dedesi Hüseyin b. Ali b. Ebû Tâlib'tir" şeklinde geçmektedir. Bu yaklaşım, Şa' rânî'nin yaklaşımına paralel olduğu gibi, İsnâaşeriyye Şîasını da doğrulamaktadır. Bkz. Muhyiddîn İbnü'l-Arabî, el-Fütûhâtü'l-Mekkiyye, haz. Ahmed Şemseddîn, (Beyrut: Darü'l-kütübi'l-ilmiyye, ts.), VI, 51.

\begin{tabular}{|c|c|c|}
\hline âm Araștırmaları & $\begin{array}{l}\text { Kelâm Araştırmaları Dergisi } \\
\text { Journal of Kalâm Researches } \\
\text { [KADER-e-ISSN: 1309-2030] }\end{array}$ & $\begin{array}{c}\text { C.: } 14, \quad \text { S.: } 1 \\
\begin{array}{c}\text { V.: } 14, \quad \text { I.: } 1 \\
2016\end{array}\end{array}$ \\
\hline
\end{tabular}


Rabbinin nezdinde bir gün, sizin saydığınız bin yıl gibidir" 5 meâlindeki âyette ifade edildiği gibi, uzun süreli bir zaman dilimi olduğunu kaydetmektedir. Söz konusu değerlendirmeler Şa'rânî'nin yaşadığı dönemde Mısır'da, Osmanlılar'ın hâkimiyeti ile başlayan ve siyasî-fikrî arayışlara yol açan bir iklimin hüküm sürdüğü dikkate alınarak, okunmalıdır. Zira genel olarak Şa'rânî, Osmanlı yönetimi ile iyi geçinmiş ve aleyhlerinde herhangi bir faaliyetin içinde yer almamış ise de, onların Mısır' fethederek hilâfeti almalarından memnun olmadığı da bilinmektedir. ${ }^{6}$

Şa'rânî gibi Osmanlılar döneminde yaşayan başka müellifler de zaman zaman Mehdîlik konusuna değinmiştir. Ancak Şa'rânî'nin konuya literatürde buna gösterilen alâkadan daha fazla ilgi göstermesi, onun bu meseleye getirdiği yorum ve açıklamalar, mehdîliğin sosyo-psikolojik değerlendirilmesi açısından önemlidir. Zira mehdînin zuhûrunun kıyâmet alâmetleri arasında sayılması yaygın olarak görülmekte ise de, bunun söz konusu alâmetlerin en başına alınması alışılagelen bir durum değildir. Kaldı ki birçok akâid risâlesi, kıyâmetin alametleri arasında buna yer bile vermemektedir. Şa'rânî'nin yaşadığı dönemin Mısır'ın Yavuz sultan Selim tarafından fethedilmesi ve Hilâfetin Memlüklerden alınarak İstanbul'a taşınması sürecine denk geldiğini, dikkate aldığımızda, Mehdîlik ve kurtarıcı beklentisini anlamak daha da kolay olacaktır. Zira siyasî dalgalanmaların bu beklentilerle doğrudan bir ilişkisi bulunmaktadır.

Osmanlı târihî boyunca, zaman zaman dini temsil konumunda bulanan şahsiyetlerin protest bir tavır içerisine girerek, mevcut yönetime karşı siyâsî boyutları da içeren bir söylem ve eylem potansiyeli barındırdıkları bir vâkıadır. Bu şahsiyetlere zaman zaman etrafındaki kimseler tarafından "mehdîlik" görevi yüklenmiştir. Ancak onların hem yazdıkları telifât hem de söylemleri dikkate alındığında, kendilerinin böyle bir düşünceye sahip olmadıkları anlaşılacaktır. Bunlardan biri de Şeyh Bedreddin'dir (ö. 823/1420)7. Kimi yazar ve araştırmacılar Şeyh Bedreddin'i de mehdî olarak görmek istemiştir. Ancak o, yazmış olduğu Vâridât adlı eserde belirttiği gibi, mehdîliğin akıl kârı olmadığını, Müslümanlar uzun süreden beri kıyâmet alâmetlerini ve Mehdî'yi beklediklerini, ancak ne bu alâmetlerin gerçekleştiğini, ne de mehdînin çıktığını belirtmiştir. Aslında onun çevresinde Anadolu'dan ve Rumeli'nin çeşitli yerlerinden gelen büyük bir halk kitlesi toplanmıştı. Bunlar Bedreddin'i mehdî olarak görme eğilimindeydiler. Ancak Şeyh Bedreddin, onlara kendisinin mehdî olmadığı

el-Hacc 22/47.

Geniş bilgi için bkz. Michael Winter, "Onaltıncı Yüzyılda Şa'râni ve Mısır Toplumu", Çev. Mahmut Çınar, Marmara Üniversitesi İlahiyat Fakültesi Dergisi [İstanbul Yüksek İslâm Enstitüsü Dergisi], 41/2 ( 2011): 275-296.

7 Geniş bilgi için bkz. Fahrettin Öztoprak, "Balkan Türkleri ve Şeyh Bedrettin", http://www.academia.edu/7862652/BALKAN_TÜRKLERI VE_ȘEYH_BEDRETTIN (Erişim: 15 Temmuz 2015), s. 62-63; 101-102.

\begin{tabular}{|c|c|c|}
\hline  & $\begin{array}{l}\text { Kelâm Araştırmaları Dergisi } \\
\text { Journal of Kalâm Researches } \\
\text { [KADER-e-ISSN: 1309-2030] }\end{array}$ & $\begin{array}{cc}\text { C.: } 14, \quad \text { S.: } 1 \\
\text { V.: } 14, \quad \text { I.: } 1 \\
2016\end{array}$ \\
\hline
\end{tabular}


gibi, İslâm'da böyle bir şeyin gerçekleşmeyeceğini söyleyince, etrafındaki bu gruplar dağılmış, yanında çok az kimse kalmıştı. ${ }^{8}$

\section{Mehdîlik Literatürüne Örnek Eserler}

Osmanlı târihî boyunca Mehdîlik etrafında kaleme alınmış zengin bir literatür yoksa da, başta Süleymaniye Kütüphanesi olmak üzere, kütüphaneler tarandığında bu meseleye dâir pek çok müstakil risâlenin bulunduğu, bazı eserlerde de bu konuya bölüm olarak yer verildiği görülmektedir. Osmanlılar döneminde kaleme alınan ve ülkemizin çeşitli kütüphanelerinde yer almakta olan risâlelere şunu örnek vermemiz mümkündür: Ahmed b. Abdullah Hadimi, Risâle fi Meciyi'l-Mehdi, Adana İl Halk Kütüphanesi, nr. 1027. Bu risâlenin 13b-174a varakları konuyla ilgilidir. Ayrıca yazarları bilinmeyen şu risâleler zikredilebilir:

- Mehdi Hakkında Bir Risâle, Süleymaniye ktp., Hacı Mahmûd Efendi, nr. 1930/2. Bu yazma nüshanın 20-29 varakları, Mehdîlik hakkında vârid olan rivâyetleri içermektedir.

- Âhir Zamanda Mehdî; Deccâl; Yecûc ve Mecûc Zuhûr Hakkinda Risâle, Süleymaniye ktp., Zühdü Bey, nr. 96/2. Eserin 89-92 varakları Mehdîlik hakkındadır.

- Risâle fi hurûci'l-mehdî, Süleymaniye ktp., Hacı Mahmûd Efendi, nr. 594-02. Eserin 11-588 varakları Mehdîlik hakkındadır.

- Risâletü'l-Mehdîye, Süleymaniye ktp., Şehid Ali Paşa, nr. 2893-01. Hicrî 1093 yılında yazılmış olan ve yedi varaktan oluşan bu yazma risâle Osmanlıca olarak kaleme alınmıştır.

- Risâle fì nüzûli Îsâ ve hurûci'l-Mehdî, Süleymaniye ktp., Ayasofya, nr. 4795-19 İki yüz bir varaktan oluşan bu risâle, Arapça olarak kaleme alınmıştır.

Bir fikir vermesi açısından söz konusu risâlelerden birini örnek olarak sunmanın maksadın hâsıl olmasına yardımcı olacağını düşünüyoruz. Örnek olarak seçtiğimiz risâle, Mısrî Efendi ${ }^{9}$ tarafından kaleme alınan ve kıyâmetin alâmetlerini tadâd eden er-Risâle fíl-Mehdiyye isimli eserde, Mehdî'nin zuhûru da kıyâmet alâmetleri arasında sayılmaktadır. Mısrî Efendi, burada kıyâmet alâmetlerine birtakım sembolik ve mistik anlamlar yüklemektedir. Bu risâlede Mehdî'nin zuhûruna ayrılan kısımda yer alan ifadeler aynen şöyledir: "Mehdî'nin çıkmasından ibarettir"10. Akıl ve rûh-i a'zâmın zuhûrudur kim evvel rûh, havâssa nefhâ-i Rahmânla olur, herkeste olmaz.

Öztoprak, “Balkan Türkleri ve Şeyh Bedrettin”, s. 62-63; 101-102.

Vefât târihî tesbit edilememiştir.

Kıyâmetin alametlerinden bahseden bir bölümün devamı olduğu için cümle bu şekilde metinde yer almaktadır.

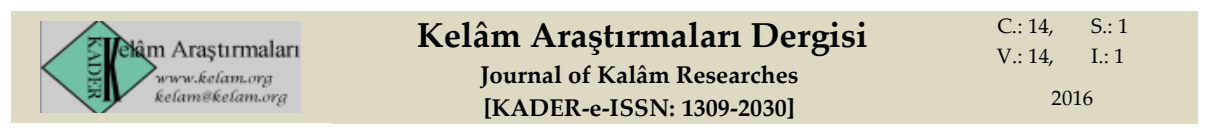


bu rûha işarettir. Bu dahi mürşid-i kâmil Allah'tan halife olup tâlibe rûh nefheder. Buna mâye-i Muhammediyye derler". ${ }^{11}$

Görüldüğü gibi Mısrî Efendi'nin bu risâlesinde Mehdîlik hakkında oldukça muhtasar bilgi verilmekte, eserde konunun teorik alt yapısı hakkında detaylı bilgiler bulunmamaktadır. Bununla beraber yukarıda belirtildiği gibi Osmanlılar'ın kriz dönemlerinde (XIV, XVII ve XIX yüzyıllar), yaşanan sosyal ve siyasal kriz ortamına paralel olarak mehdîlik düşüncesi etrafında çeşitli çarelerin üretilmesine çalışılmıştır. Bu dönemlerde ortaya çıkan hareketler ve kaleme alınan eserler, kurtarıcı düşüncesinin canlı bir biçimde temellendirilmeye çalışıldığı görülmektedir. $\mathrm{Bu}$ hareket ve değerlendirmelere ışık tutması açısından, XIII. yüzyılda ortaya çıan ve Mehdîlik düşüncesi etrafında Müslüman toplumu bir araya toplama gayreti içerisine giren "Demirtaş [Timurtaş] Mehdî olayı" ile bunu konu edinen Sema Yaniç'in çalışması, XVII. yüzyılda meydana gelen siyasal krize paralel olarak tarihçi Naîmâ tarafından ortaya atılan "Büyük Adamlar" düşüncesi ve Osmanlı Devleti'nin yıkılışına sahne olan XX. yüzyılın başlarında M. Ali Takyeddin ve İzmirli İsmail Hakkı tarafından kaleme alınan makaleler üzerinden konunun aydınlatılmasına çalışılacaktır.

\section{XIV. Asırda Anadolu'da Yaşanılan Siyasî Krizler ve Bu dönemde Ortaya Çıkan Timurtaş’ın Mehdîliği Meselesi}

Anadolu'da mehdîlik iddiasıyla ortaya çıkan şahsiyetlerin târihî, Selçuklular'ın İran üzerinden Anadolu'ya girdikleri döneme kadar gitmektedir. Ancak Selçuklular'ın ilk dönemlerinden daha çok, güçlerini kaybederek Anadolu'da bir inkırâz ve kaos ortamının hüküm sürdüğü dönem olan XIII. ve XIV. yüzyıllarda, bu beklentinin daha bâriz bir şekilde ortaya çıtığı görülmektedir. Daha önceleri başka örnekleri de bulunmakla beraber, bu konuda en fazla dikkat çeken şahsiyet, 1322 yılında kendisini "Mehdî-i âhirzamân" olarak ilân eden İlhanlılar'ın Anadolu umûm valisi Timurtaş'tır ${ }^{12}$. İlhanlılar'ın tahtında bulunan ve Şiîliği âdetâ bir devlet mezhebi olarak kabul eden atalarının yolunu takib eden Olcaytu'dan sonra, küçük yaşta tahta geçen Ebû Saîd Bahadır Han döneminde (717/1317736/1335)13, Emir Çoban, Beylerbeyi görevini deruhte ederek önemli bir nüfûz alanı sağlar. Onun oğlu olan Timurtaş ${ }^{14}$ da hem mülkî hem de askerî

11 Misrî Efendi, er-Risâle fíl-Mehdiyye, Süleymaniye Kütüphanesi, Tercüman Bölümü nr. 00456, vr. 3b.

12 Bu konuda Sema Yaniç'in Selçuk Üniversitesi Illahiyat Fakültesi Dergisi'nde yayımlanan "XIV. Asrın İlk Yarısında Anadolu'da Mehdî Bekleme Temâyülü ve Timurtaş'ın Mehdiliği Meselesi” başlıklı makalesi esas alınmıştır. Bkz. Sema Yaniç, "XIV. Asrın İlk Yarısında Anadolu'da Mehdî Bekleme Temâyülü ve Timurtaş'ın Mehdiliği Meselesi", Selçuk Üniversitesi İlahiyat Fakültesi Dergisi, 30 (2010): 181-195.

13 Geniş bilgi için bkz. Abdülkadir Yuvalı, "İlhanlılar", TDV İslam Ansiklopedisi (DİA), XXII, 102-105; Abdülkadir Yuvalı, "Ebû Said Bahadır Han”, TDV İslam Ansiklopedisi (DİA), X, 218-219.

14 Bu zât, Timurtaş veya Demirtaş şeklinde anılır. Her ikisi de aynı kişiye işaret etmektedir.

\begin{tabular}{|ccc} 
Kelâm Araştırmaları Dergisi & C.: 14, & S.: 1 \\
Journal of Kalâm Researches & V.: 14, & I.:1 \\
[KADER-e-ISSN: 1309-2030] & 2016
\end{tabular}


en üst yetkili olarak Anadolu'da görevlendirilir. Selçuklular'ın zayıflamasından sonra önemli siyasî buhrânlar geçiren Anadolu'da hem birliği sağlama hem de halkın refâh düzeyini yükselterek, önemli ölçüde toplumsal huzur ve düzeni sağlamaya muvaffak olur.

Düşmanlarına karşı oldukça acımasız davrandığı halde halka karşı cömert, dindar, âdil ve nizamdan yana bir tavır sergiler. Onun bu tutumu halk arasında önemli ölçüde kabul görür. Kerîmüddîn Aksarâyî (ö. 733/1332-33), eserinde Timurtaş'a ithaf ettiği Anadolu Selçukluları tarihinin en önemli kaynaklarından biri olan Müsâmeretü'l-Ahbâr ${ }^{15}$ adlı eserinde onu şu şekilde tasvir etmektedir: “Hüsrev-i Âdil'in günlerinde Tanrı'nın büyük bir lütuf eseri olarak fitne ve fesat kalktı. Memleket baştanbaşa temizlendi. Cennet, yılan ve şeytandan kurtuldu. Ancak âdemin nefsine kavuştu. Karışıklıklar, haksızlıklar, zulümler artık yer bulmaz oldu. Yeryüzü bu adaletli hükümdarın şan ve şefkatiyle, ihsânlarıyla gülümseyen bir gül gibi pembeleşti. Memleket ile adalet birbirini tamamlayan iki temeldir. Memleket ve devlet, adalet ve ihsan ile düzen bulur. Sultanların işledikleri hatanın cezası ancak ihsânla muâmele etmektir. Tanrı Hüsrev-i Âdil Timurtaş'a sanki kerâmet donu giydirmiştir. Onun devletinin töresi sanki adalet, ihsân ve insaftır. Zâlimlerin tecavüz ellerini mazlûmların yakasından ayırdı. Her kim Allah için çalışırsa Allah da ona yardımcı olur. Şüphe yok ki bu sultan "Tanrı mülkü dilediğine verir" meâlindeki âyetin feyizli hazinesinden giyinmiş olduğu kerâmet libâsını zamanın değişmesiyle soyunmayacaktır."16

Aksarayî'nin Timurtaş hakkında yaptığı bu tasvirler, onun mehdîlik iddiasını tasdik edercesine, "Âhir zaman mehdîsi" hakkında yapılan tasvirlere bire bir uymaktadır. Aynı müellif devamla Timurtaş'ın Muhyiddîn İbnü'l-Arabî'nin zımmîlerle ilgili tavsiyelerini dinlemeyen İzzeddin Keykavus'un aksine, bu tavsiyeleri olduğu gibi kabul ederek hayata geçirdiğini belirtmek suretiyle, Mehdîlik iddiasında bulunan Timurtaş ile İbnü'l-Arabî arasında bir bağlantı kurmaktadır. ${ }^{17}$ Şu var ki Timurtaş'ın Mehdîlik iddiası hakkında iki temel ve farklı görüş bulunmaktadır: Bunlardan birincisine göre, Timurtaş'ın ortaya çıktığı ortam ve onun uygulamalarını dikkate alan başkaları tarafından mehdî ilân edilmiştir. Başta Aksarayî olmak üzere, ulemâ sınıfının onun hakkında

15 Eser önce Osman Turan tarafından geniş bir mukaddime ve hâşiyeler eklenerek neşredilmiş (Ankara: TTK Yayını, 1944); daha sonra da eseri Mürsel Öztürk Türkçe'ye çevirerek yayımlamıştır (Ankara: TTK Yayını, 2000).

16 Yaniç, "XIV. Asrın İlk Yarısında Anadolu'da Mehdî Bekleme Temâyülü ve Timurtaş'ın Mehdiliği Meselesi", 188.

17 Yaniç, “XIV. Asrın İlk Yarısında Anadolu'da Mehdî Bekleme Temâyülü ve Timurtaş'ın Mehdiliği Meselesi", 188.

\begin{tabular}{|c|c|c|}
\hline 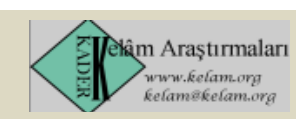 & $\begin{array}{l}\text { Kelâm Araştırmaları Dergisi } \\
\text { Journal of Kalâm Researches } \\
\text { [KADER-e-ISSN: 1309-2030] }\end{array}$ & 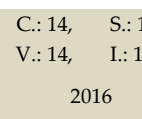 \\
\hline
\end{tabular}


yaptığ1 değerlendirmeler bu görüşü desteklemektedir. ${ }^{18}$ Gerçekten de Timurtaş'ın Anadolu'da hâkimiyet kurmasından önceki dönem, ciddî bir şekilde siyasî ve ictimai kaos dönemleri geçirmiştir. Halk, meydana gelen savaş ve kriz ortamından bıkmış, kendilerini bu ortamdan kurtaracak birilerini arar hale gelmişti. Zemin, Mehdîlik inanç ve düşüncesinin güçlenmesi için tamamen müsaitti. Böylesi bir ortamda ortaya çıkarak, düşmanlarına karşı acımasız, tebaasına karşı ise oldukça merhametli bir portre çizmiş olması, onun hakkında söz konusu değerlendirmelerin yapılmasına sebep olmuş olabilir. İkinci görüşe göre ise, Timurtaş'ın bizzat kendisi, etrafında yer alan kimselerin de etkisiyle, mehdîliğin nüfûzundan yararlanmak için bu iddiayı ortaya atmıştır. Yaptığı icraatlarda da mehdî için literatürde yer alan tasvirleri dikkate alarak onun bu iddiasını desteklemeye çalışmış olması mümkündür. ${ }^{19}$

Timurtaş, Ebû Saîd Bahâdır'la arası açılan babası ve kardeşinin öldürülme haberini aldıktan sonra, Mısır'a kaçarak Memlük hükümdarı Melik enNâsır'a sığınır. Bu dönemde Nâsır nezdinde hem Moğollar hem de Karamanoğulları faaliyetlerde bulunmaktaydı. Bunların ikisi de sürekli Timurtaş'ın Nâsır için potansiyel bir tehlike olduğunu ileri sürerek aralarını açmayı başardılar. Neticede Timurtaş 1328 yılında Nâsır tarafından idam edilmiştir. ${ }^{20}$

Netice itibariyle, Timurtaş'ın mehdîliği etrafında yazılanlar, teorik değerlendirmelerden daha çok, mevcut yönetime muhâlefet olarak ortaya çıkan bir hareketin kendisini mehdîlikle bütünleştirerek, geniş halk kitleleri tarafından kabul edilebilirliğini sağlamaya çalıştığını göstermektedir. Bu anlamda Timurtaş'ın halka karşı adil, düşmanlarına karşı ise acımasız olduğu gibi, tasvirlerin ilgili literatürde yer almasını, müellifler açısından söz konusu iddianın kısmen de olsa benimsendiğine dâir bir işaret olarak kabul etmek mümkündür. Timurtaş'ın şahsiyeti etrafında oluşturulan ve Mehdîlik ve Beklenen kurtarıcı temalı değerlendirmeler, tamamen siyasi bir bunalım içindeki çevrelerin bu krizden kurtulmak için söz konusu inanç ve literatürden yararlanma çabası olarak karşımıza çıkmaktadır.

\section{XVI. Yüzyılda Duraklama ile Birlikte Başalyan Siyasi Arayışalar, Mehdîlik ve Tarihçi Naîmâ'nın “Büyük Adamlar Teorisi"}

Asıl adı Mustafa olan tarihçi Naîmâ (ö. 1128/1716), aslen Haleplidir. "İlk resmî Osmanlı vak'anüvisi” olarak bilinir. İlk eğitimini Halep’te aldıktan

\footnotetext{
18 Yaniç, “XIV. Asrın İlk Yarısında Anadolu'da Mehdî Bekleme Temâyülü ve Timurtaş'ın Mehdiliği Meselesi", 189-190.

19 Yaniç, “XIV. Asrın İlk Yarısında Anadolu'da Mehdî Bekleme Temâyülü ve Timurtaş’ın Mehdiliği Meselesi", 190.

20 Yaniç, “XIV. Asrın İlk Yarısında Anadolu'da Mehdî Bekleme Temâyülü ve Timurtaş'ın Mehdiliği Meselesi", 186.
}

\begin{tabular}{|c|c|c|}
\hline elâm Araştırmaları & $\begin{array}{l}\text { Kelâm Araştırmaları Dergisi } \\
\text { Journal of Kalâm Researches } \\
\text { [KADER-e-ISSN: 1309-2030] }\end{array}$ & $\begin{array}{c}\text { C.: } 14, \quad \text { S.: } 1 \\
\begin{array}{c}\text { V.: } 14, \quad \text { I.: } 1 \\
2016\end{array}\end{array}$ \\
\hline
\end{tabular}


sonra 1091 (1680) yılı civarında İstanbul'a gider. Naîmâ vak'anüvis olarak öncelikle, Amcazâde Hüseyin Paşa tarafından Şârihülmenârzâde Ahmed Efendi'nin yazdığı târihîn müsveddelerini temize çekmekle görevlendirilir. Tarihle doğrudan ilgisi bu şekilde başlamış olur. İstanbul'da teşrifâtçılık ve divitdârlık, Anadolu muhasebeciliği, defter emîni, baş muhasebeci, silâhdâr kâtipliği, defter emâneti vekâleti gibi görevlerde de bulunur. Yunanistan'da Mora Yarımadası'nın batısında yer alan ünlü liman şehri Balyabadra'da (Batros) Şâban 1128' de (Ağustos 1716) vefat etti. ${ }^{21}$

Naîmâ, Târîh-i Naîmâ olarak bilinen ve asıl adı Ravzatü'l-Hüseyn fî hulâsati ahbâri'l-hâfikayn olan eseriyle Osmanlı tarihçiliğinde önemli bir yere sahip olmuştur. Kronolojik olarak kaleme alınan bu eser renkli tasvirleri, romanvâri anlatımı, nükteli, îmâlı ifadeleri ve olayların iç yüzünü anlatmada gösterdiği titizlikle büyük ilgi çekmiş ve başka hiçbir tarihe kısmet olmayan bir şöhret kazanmıştır. Naîmâ'nın târihî aslında, Şârihulmenârzâde'nin günümüze ulaşmayan ve yaratılıştan 1065 (1655) yılına kadar gelen târihînin müsveddelerini kullandığını, onun I. Ahmed devrinden Köprülü Mehmed Paşa'ya kadarki dönemi geniş bir şekilde yazdığını, daha önceki dönemleri ise Hasanbeyzâde Târihi'nden aldığını belirtir. ${ }^{22}$

Naîmâ'nın bu eserinin mukaddime kısmı ayrı bir öneme sahiptir. Burada Naîmâ'nın tarihçilik anlayışı ve siyasetnâmeyle ilgili görüşleri yer almaktadır. Bu kısım İ̉bn Haldûn, Âlî Mustafa Efendi ve Kâtib Çelebi gibi müelliflerin fikirlerinden hareketle hazırlanmıştır. Naîmâ târih $\hat{\imath}$, muhteva itibariyle olayları kronolojik bir sıra içerisinde nakleden geleneğe sıkı sıkıya bağlıdır. Bu eser, Osmanlı ve Cumhuriyet dönemlerinde çok kullanılan, okunan bir eser olmuştur. Naîmâ ve târihî üzerine çeşitli çalışmalar yapılmıştır. Bunların ilki Lewis V. Thomas'ın doktora tezidir. Thomas çalışmasını Naîmâ'nın hayatı, fikirleri ve eseri olmak üzere üç bölümde düzenlemiş ve tarihçinin hayatı ve eseriyle ilgili birçok noktayı aydınlatmıştır. İkincisi Zeki Arslantürk'ün Naîmâ'ya Göre XVII. Yüzyıl Osmanlı Toplum Yapısı (İstanbul 1997) adlı sosyoloji çalışmasıdır. ${ }^{23}$

Naîmâ'nın yaşadığı dönem, Osmanlı Devleti'nin cihan imparatorluğundan duraklama dönemine geçiş dönemidir. Bu dönemde 'Devlet-i Aliye'de baş gösteren düşüş, Naîmâ'nın dikkatini çekmiş ve yeni teorik arayışlar içerisine girmiştir. Naîmâ'nın bu süreçte oluşturarak târihîne kaydettiği teorik çerçeve tam olarak Mehdîlik etrafında oluşturulan teorilerle örtüşmemekte ise de neticede bir kurtarıcı fikrini öngördüğünden bu kapsamda değerlendirmek mümkündür. Zira Naîmâ'nın "Büyük Adam" teorisi ile Mehdîlik teorisinin her ikisi de kriz sürecinde bulunan bir toplumu

21 Mehmet İpşirli, “Naîmâ”, TDV İslam Ansiklopedisi (DİA), XXXII, 317-318.

22 Geniş bilgi için bkz. İpşirli, "Naîmâ", 317-318.

23 Bu çalışma esas itibariyle Naîmâ'nın giriş kısmındaki değerlendirmelerine dayanır. Târîh-i Naîmâ'nın Batı dillerine kısmî çevirileri de vardır. Bkz. İpşirli, "Naîmâ”, 317-318.

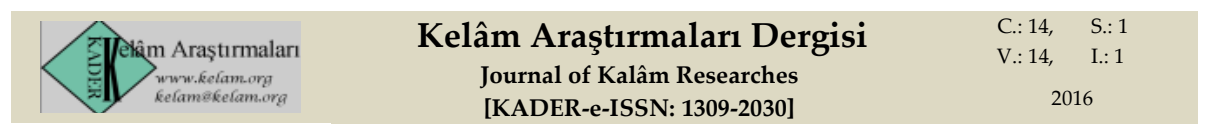


kurtarmayı hedeflemekte ve söz konusu kurtarıcının karizmatik bir şahsiyet olmasını öngörmektedir. Şu var ki Naîmâ ortaya koyduğu teorinin zihinsel temellerinin farkında olduğundan bunu dinî bir inanç ve öngörüden daha ziyade, sosyolojik bir ihtiyaç ve olgu olarak sunmaktadır. Naîmâ'nın kurtarıcı olarak ön gördüğü "büyük Aaam tasavvuru" etrafında yaptığı betimlemeleri özetlediğimizde, bununla mehdîlik etrafında yapılan değerlendirmelerin ana tema itibariyle ne kadar benzeştiği ve ne kadar ayrıştı̆̆ı daha açık bir şekilde anlaşılacaktır.

Sarsılan Osmanlı saltanatının etkin bir şekilde varlığını sürdürmesi üzerine kurduğu teorisini temellendiren Naîmâ, büyük adam için bir takım özellikler öngörmektedir. Onun muhalled eseri olan Târîh'inde, çoğu zaman gerekçeleriyle birlikte belirlediği bu özellikleri maddeler halinde şöyle sıralamak mümkündür. ${ }^{24}$

1. Büyük Adam, her zaman ve her yerde kendisine çokça rastlanılan bir şahsiyet değil, nâdir bulunan bir kişiliktir. ${ }^{25}$ Gerçekten de kurtarıcı şahsiyetin kriz dönemlerinde ortaya çıkarak, bozulmuş olan dengeleri islâh ederek kurtuluşa kavuşturacağına dâir mülâhazalar dikkate alındığında, bu özelliğin teorinin tabiatında zâten var olduğu görülmektedir.

2. "Büyük Âdam", mehdîlik etrafında yapılan değerlendirmelerde varılan neticelerin aksine, sadece âhir zamanda zuhûr edecek olan bir kişiden ziyâde, her çağda bulunması mümkün olan kriz dönemlerinde ortaya çıarak vaziyet alması beklenen bir şahsiyettir. Ayrıca Naîmâ, "Büyük Adam"ın kendi dönemindeki insanların sosyal hayat, imkân ve değer yargılarını dikkate alması gerektiğini ileri sürmekte, onun ânı idrâk etmesi gerektiğini dikkat çekmektedir. Naîmâ'nın bu anlamda: “Âdem oldur ki, bulunduğu asr ricâlini selb itmeye ve bu vakitte filân vakit gibi hareket olunsun deyû mizâc-1 âleme mugâyir vaz'i [uygulama] makûl görmiye" şeklindeki cümleleri çarpıcıdır. Naîmâ'ya göre "Büyük Adam" sosyolojik bir olay olduğundan onun metafizik ve mistik bir yönünün olması aranmaz. Bununla beraber metafizik boyut, şartların bir neticesi olarak bu konunun kapsamına dâhil edilmiştir. Metafizik bağlantıların dâhil olması da, başta Osmanlı Devleti coğradyasında yaşayanlar olmak üzere dinî şahsiyetlerin bu kategoriye dâhil olmasına zemin hazırlamıştır. ${ }^{26}$ Onun "Büyük Adam"ın çağının adamı olması gerektiğine dâir bu değerlendirmesi ile ortaya koyduğu salt sosyolojik kural, İbn Haldûn'un toplum içerisinde Amr b. Âs gibi ileri düzeyde zeki olan insanların yönetime gelmemesi gerektiğine dâir görüşüyle örtüşmektedir. Buna göre bu tür şahsiyetler, ileri görüşlü

24 Naîmâ'nın konu hakkındaki değerlendirmeleri hususnda, onun "Büyük Adam Teorisi” üzerinde çalışmalar yapan Ali Coşkun'dan sıklıkla istifade edilmiştir. Bu amaçla söz konusu müellifin "Naîmâ'nın Din ve Cemiyet Görüşü", (yüksek lisans tezi, Erciyes Üniversitesi Sosyal Bilimler Enstitüsü, 1990) ve Osmanl da Din Sosyolojisi (İstanbul: İz yayıncılık, 2004) isimli eserleri esas alınmıştır.

25 Coşkun, Osmanli'da Din Sosyolojisi, (İstanbul: İz yayıncılık, 2004), s. 148.

26 Naîmâ, Tarih, VI, 190-193; Coşkun, Osmanlı da Din Sosyolojisi, s. 149.

$\begin{array}{ccc}\text { Kelâm Araştırmaları Dergisi } & \text { C.: 14, } & \text { S.: } 1 \\ \text { Journal of Kalâm Researches } & \text { V.: 14, } & \text { I.: } 1 \\ \text { [KADER-e-ISSN: 1309-2030] } & 2016\end{array}$


olmalarından dolayı, içinde bulundukları toplum tarafından tam olarak anlaşılmayan bir takım radikal sosyal tedbirler alabilirler. Bu tedbirlerin, halk tarafından maksadına uygun olarak anlaşılmaması mümkündür. Bu durumda Söz konusu yanlış anlamaların da halkta rahatsızlıklara sebebiyet vermesi ihtimâl dâhilindedir. ${ }^{27}$

3. Naîmâ'ya göre "Büyük Adam", sıradan ve her kesimden değil, idârî ve ilmî kesim arasından seçilmelidir. Ona göre "Büyük Adam", padişah, vezir, şeyhülislâm ve bunlara danışmanlık yapan askerî ve ilmî şahsiyetler arasında aranmalıdır. Yani kalem ve kılıç erbâbı olmalıdır. ${ }^{28}$ Onun bu yaklaşımı ile mehdînin mutlak iktidar sahibi ve bilge kişi olması gerektiğine dâir yapılan değerlendirmeler arasında büyük ölçüde paralellik bulunmaktadır.

4. Şîa'da Mehdî'nin mâsûmiyeti esastır. Zira İmâm Mehdî, mâsûm olarak kabul edilen imâmların on ikincisidir. Sünnî tasavvuf çevreleri de Mehdî'yi velâyet mertebelerinin zirvesinde olan bir kişi olarak kabul ettikleri için onu en azından veliler için ön görülen "hıfz" vasfını taşıyan bir zât olarak kabul etmektedirler. Buna karşılık Naîmâ, Büyük Adam'ın ne mâsûm ne de mahfûz olmasını öngörmektedir. Ona göre iyiliklerinin onun kötülüklerinden daha fazla olması yeterlidir. Onun: “Cemî-i uyûb ve nekâisten hâlî âdem dünyada bulunmaz. Ancak hüsn-i hâli kubhiyyâtına gâlib olan nefsü'l-emirde memdûh olan ricâl-i ekâbir zümresinden mâdûd olagelmiştir" şeklinde yaptığı tasvir, Büyük Adam için öngördüğü ahlâkî ve fiilî zemin hakkında nasıl bir durum düşündüğünü açıkça ortaya koymaktadır. Zira ona göre Hz. Peygamber ve Halifeler döneminden sonra salt adalet ve itidâl ortamını sağlamak ve bunu her an korumak mümkün olmamıştır ve her halde olmayacaktır da. ${ }^{29}$

5. Mehdînin iktidarı ve ona muhâlefet edenler hakkında detaylı tasvirlerde bulunan Mehdîlik inancı mensupları, Mehdîye muhâlefet edenlerin daha çok bağnaz ve şekilci ulemâ olduğunu ileri sürmektedirler. ${ }^{30}$ Ancak Naîmâ'ya göre, buna itiraz ve muhâlefet edecek olanlar, devletten menfaat elde etmeyen; devletin uygulamalarından mağdur olan ve zarar görenler, sürekli ayıpları gözetleyerek onun eksiklerini araştırıp dile getirirler. ${ }^{31}$ Naîmâ'nın muhâlefet tasvirinde yaptığı bu değerlendirme, onun "Büyük Adam Teorisi" ni sosyolojik bir zemin üzerine bina etmesiyle uyumludur.

6. Bunlara ilâve olarak Naîmâ, kendisinden önce kaleme alınan bir takım eserlerden de istifade ederek Büyük Adamın şu özelliklere sahip olması

27 Geniş bilgi için bk. İbn Haldûn, Mukaddime, çev. Zâkir Kadiri Ugan, (İstanbul: MEB Basımevi, 1986), II, 477.

28 Naîmâ, Târih, I, 58; Coşkun, Osmanlı'da Din Sosyolojisi, s. 150.

29 Naîmâ, Tarih, VI, 300, 411; Coşkun, Osmanlı'da Din Sosyolojisi, s. 150-151.

30 Geniş bilgi için bk. Mahmut Çınar, Mehdîlik, s. 178.

31 Naîmâ, Tarih, IV, 411; Coşkun, Osmanlı'da Din Sosyolojisi, s. 153-154.

$\begin{array}{|ccc|}\text { Kelâm Araştırmaları Dergisi } & \text { C.: 14, } & \text { S.: } 1 \\ \text { Journal of Kalâm Researches } & \text { V.: 14, } & \text { I.: } 1 \\ \text { [KADER-e-ISSN: 1309-2030] } & 2016\end{array}$


gerektiğini ileri sürmektedir: İyi niyetli, adaletli, akılll, cesur, cömert, yumuşak huylu, vefalı, doğru, şefkat ve merhamet sahibi, sabırlı, affedici, şükredici, teenni ile hareket eden, bilgili, namuslu ve vakar sahibi olmak. ${ }^{32}$

Naîmâ, saydığı bu özellikleri kendi dönemimde yaşayan Osmanlı padişahları üzerinde tatbik ederek, onlardan hangilerinin Büyük Adam tasavvuruna konu olabileceklerini araştırır. Ona göre IV. Murad, bir kısım yanlış uygulamalarından dolayı tam hizmet edecek yaşta iken çok genç yaşta vefat etti. Genç Osman, etrafında tecrübeli ve sâdık dostları bulunmadığından, kendisi de henüz çok genç ve tecrübesiz olduğundan başarılı olamadı. Aslında onun sahip olduğu kişisel donanım, buna müsaitti. III. Ahmed ile I. İbrahim, saf dil olduklarından çevrelerinin etkisinde kalarak durumun kötüye gitmesine engel olamadılar. ${ }^{33}$

Naîmâ, Büyük Adamın ortaya çıkmasının teolojik dayanakları ile sosyolojik şartların bir noktada kesişmesi gerektiği üzerinde 1 srarlı bir şekilde durmaktadır. Toplumların kriz dönemlerinde bozulan iktisadî, siyasî, fikrî ve ictimâî ortamı ıslâh etmesi için lider arayışlarının daha hararetli bir biçimde ortaya çıktığı hususnda hiç kuşku yoktur. Ona göre toplumların bozulan düzenini ıslâh eden ve onları düzenli bir yaşam ortamına taşıyan liderlerin ortaya çıkmasında, küllî irâde ile bu Büyük Adamların faaliyetleri kesişmektedir. $\mathrm{Bu}$ anlamda metafizik boyut ile sosyolojik boyut, birlikte dikkate alınmak zorundadır. Aksi takdirde salt dinî bir inanç olarak yansıtıldığı gibi, ilâhî irâdenin alâkalı-alâkasız bir dönemde tecellî etmesi söz konusu değildir. ${ }^{34}$

Naîmâ'nın sosyal olaylarla Büyük Adam Teorisi arasında kurduğu ilişkiye benzer bir ilişkiyi, tabiî olaylarla sosyal olaylar arasında kurmaya çalıştığı görülmektedir. Onun Büyük Adamların zuhûru için sosyal ortamın yanı sıra ilâhî irâdeyi ön görmesi, bütün evreni kapsayan ilâhî irâdenin insana bakan yüzünün tecellîsi ile insanların yapıp ettikleri arasında doğrudan bir bağlantı kurmasını da sağlamaktadır. Buna bağlı olarak o, söz gelimi depremin meydana gelmesini, o dönemde yapılan zulümlere bağlamıştır. ${ }^{35}$ Naîmâ'nın bu yöntemi, Kur'ân'da kıssaları anlatılan bir kısım peygamberlerle ümmetlerinin başına gelenler dikkate alındığında, çok da uç bir yorum sayılmaz. Ancak meydana gelen her türlü tabiî felâketi bu yöntemle açıklamak da çok mâkûl değildir. Bununla beraber, ona göre hem sosyal olaylarda hem de tabiî olaylarda asıl belirleyici olan ilâhî irâdedir. Yüce Allah, bir şeyin olmasını dilediği zaman bütün sebepleri ona göre düzenler, daha sonra da bu sebeplere uygun olarak muradını gerçekleştirir. ${ }^{36} \mathrm{Bu}$ yaklaşımın da problemli olduğu açıtır. Zira insan

Coşkun, Osmanlı'da Din Sosyolojisi, s. 154.

Coşkun, Osmanlı'da Din Sosyolojisi, s. 155.

Geniş bilgi için bk. Coşkun, "Naîmâ'nın Din ve Cemiyet Görüşü", s. 132-136.

Naîmâ, Tarih, . V, 276; Coşkun, "Naîmâ'nın Din ve Cemiyet Görüşü", s. 137-138.

Coşkun, Naîmâ'nın Din ve Cemiyet Görü̈sü, s. 139.

\begin{tabular}{|c|c|c|}
\hline elâm Araştırmaları & $\begin{array}{l}\text { Kelâm Araştırmaları Dergisi } \\
\text { Journal of Kalâm Researches } \\
\text { [KADER-e-ISSN: 1309-2030] }\end{array}$ & $\begin{array}{c}\text { C.: } 14, \quad \text { S.: } 1 \\
\begin{array}{c}\text { V.: } 14, \quad \text { I.: } 1 \\
2016\end{array}\end{array}$ \\
\hline
\end{tabular}


irâdesini kısmen de olsa devre dışı bırakmaktadır. Ancak tarih boyunca vaad edilen kurtarıcı ve Mehdîlik figürü etrafında yapılan bütün değerlendirmelerde, bu kurtarıcının ilâhî inâyetle zuhûr etmesi öngörülmektedir. Bu açıdan bakıldığında Naîmâ'nın "Büyük Adamlar Teorisi" çerçevesinde yaptığı değerlendirmeler, tarihteki benzerleriyle örtüşmektedir ${ }^{37}$.

Sonuç olarak "Naîmâ'nın Büyük Adamlar Teorisi", dinî bir inançtan daha çok sosyolojik bir ihtiyaç ve konjoktürel bir zorunluluğa dayanmaktadır. Ancak Naîmâ söz konusu sosyolojik süreci İlahî irâde ile bağlantı kurarak açıklamakta ve zaman zaman buna bir takım mistik unsurlar da katarak, teorisine dinî bir boyut kazandırmaktadır. Gerçekten de Naîmâ'nın zihin dünyası tahlîl edildiğinde, burada mistik ve gnostik birçok unsura rastlamak mümkündür. Kendi döneminde yaşanan krizlerden kurtuluş için onun önerdiği projelere de, aynı bakış açısının yansımış olması yadırganacak bir durum değildir.

Naîmâ, işin metafizik boyutu ve ilâhî takdir kadar sosyolojik ortam ve şartların, sadece Büyük Adamların ortaya çıkmasında değil, aynı zamanda onların başarısında da etkili olduğuna dikkat çekmektedir. Onun bu tesbiti, Mehdî'nin sanki elinde sihirli bir değnek varmış gibi, her şeyi bir anda güllük gülistânlık edeceğine dâir, Şîa ve tasavvuf çevreleri tarafından yapılan tasvirlere uymamaktadır. $O$, söz konusu süreci daha gerçekçi, sünnetullâha uygun ve eşyanın tabiatının gereği meydana gelen bir netice olarak tasvir etmektedir. Bu yüzden de vaad edilen kurtarıcının (Büyük Adam) başarılı olması için kendisinde bulunması gereken özelliklerin yanı sıra, etrafında yer alanların da tecrübeli, ileri görüşlü ve vizyon sahibi devlet adamı; kendi şahsi menfaatlerinden ziyade kamu yararını gözeten kimseler olması gerektiğine vurgu yapmaktadır.

\section{Osmanlı Devleti'nin Dağılması ve XX. Yüzyılda Mehdîlik Arayışları}

$X X$. yüzyıl, genelde bütün ümmet için, özelde ise coğrafî anlamda Osmanlı İmparatorluğu'nun merkezi konumunda bulunan İstanbul ve Anadolu için büyük sarsıntıların yaşandığı bir dönemdir. Kuşkusuz kastettiğimiz dönem XX. yüzyılın tamamı değil, bu yüzyılın Osmanlı İmparatorluğu'nun tarih sahnesinden silindiği ilk çeyreğidir. Yaşanan sarsıntı ve kriz ortamı, Osmanlı aydınları ve ulemâsı tarafından da değerlendirilmiş ve çeşitli çözüm arayışlarına girilmiştir. Bu dönemde gerek taşrada gerekse Bâb-1 Âlî̀de sorun tespit etme ve çözüm önerileri üretme adına birçok görüşme yapılmış, konuya ilişkin olarak birçok risâle ve makale kaleme alınmıştır.

37 Söz konusu kurtarıcı beklentilerine Mecûsîlikteki "Saoşyant", Yahûdîlik ve Hıristiyanlıktaki "Mesih" ve Şîa'daki "Beklenen Mehdî" inancını örnek vermek mümkündür. Geniş bilgi için bk. Çınar, Mehdîlik, s. 29-47.

\begin{tabular}{|c|c|c|}
\hline (elâm Araştırmaları & $\begin{array}{l}\text { Kelâm Araştırmaları Dergisi } \\
\text { Journal of Kalâm Researches } \\
\text { [KADER-e-ISSN: 1309-2030] }\end{array}$ & $\begin{array}{c}\text { C.: } 14, \quad \text { S.: } 1 \\
\begin{array}{c}\text { V.: } 14, \quad \text { I.: } 1 \\
2016\end{array}\end{array}$ \\
\hline
\end{tabular}


Söz konusu tartışma ve yazılar, Osmanlı İmparatorluğu'nun niçin bu duruma düştügünü tesbit etmek üzere yapılan değerlendirmeleri içerdiği gibi, bu mâkûs durumdan kurtulmanın nasıl ve hangi yöntemlerle kurtulunabileceğine dâir mülâhazaları da içermektedir.

Osmanlı halkları arasında farklı inanç ve kültür çevreleri bulunmakla beraber, biz bu çalışmamızda teba içinde aslî unsur konumundaki Müslümanların bu konudaki arayışlarını merkeze almış bulunuyoruz. Kuşkusuz bu coğrafyada yaşayan azınlıkların da, aynı konuda çeşitli arayışlara girmiş olması mümkündür. Hattâ XIX ve XX. yüzyıllarda Sabatay

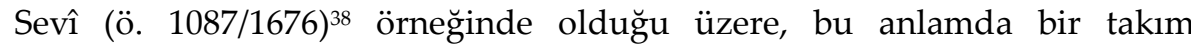
hareketlenmelerin olduğu kuşkusuzdur. Ancak biz, azınlıkların bu anlamdaki arayış ve çabalarını konumuzun dışında tuttuk. Osmanlı tebasındaki Müslüman çoğunluk, mevcut inanç ve kültürlerini bu arayışlara yansıtmış, toplumda yaşanan kriz ve buhranlarda kurtuluş çareleri ararken, buralardan kendilerine destek olmak üzere referanslar almışlardır. Osmanlı halkları gibi aydınları da, ciddi bir şekilde tasavvuf düşüncesinin tesiri altında kalmıştır. Buna bağlı olarak, kriz durumu yaşayan herkes gibi, bunlar da "Mehdîlik" inancı etrafında oluşan düşünceyi krizden kurtuluş arayışlarına yansıtmışlardır. Nitekim bu konuya ilişkin eserlerde öncelikle salt mehdîlik konusunun teorik zemini tartışılmış, yaşanılan süreçten kurtuluşun çareleri aranırken de, satır aralarında bu konuya dolaylı atıflar da bulunulmuştur. Osmanlı Devleti'nin âdetâ can çekiştiği ve daha sonra da tarihe gömüldüğü bu süreçte kaleme alınan, biri mehdîliğin teorik arka planını irdeleyen bir makale, diğeri de söz konusu krizden kurtulmanın çarelerini arayan bir risâle olmak üzere iki eseri çalışmamızın bu kısmında örnek alarak kullanarak değerlendirmeye çalışacağız. Birincisi Bâb-1 Âlı̂'de yaşayan ve dönemin matbûât çevrelerinde oldukça tanınan, yazılarıyla, tartışmalarıyla ve çözüm önerileriyle dikkatleri çeken İzmirli İsmail Hakkı'nın bir makalesidir. Diğeri ise taşrada, Eskişehir'de yaşayan Mehmed Ali Takyeddin'in Mehdî başlıklı isimli risâlesidir. Her iki çalışma bu sıralamaya göre ele alınacak, böylelikle Osmanlı Dönemi mehdîlik literatürüne ışık tutulmaya çalışılacaktır.

\section{İzmirli İsmail Hakkı, "Mehdî Meselesi", Sebîlürreşâd Mecmûası, 33/285 (13 Şubat 1329 / 30 Rebiülevvel 1332), s. 389- $391^{39}$}

İzmirli İsmail Hakkı (ö. 1868-1946), Sebîlürreşşâd isimli haftalık mecmûada "Kelâm" ana başlığı altında yer alan "Mehdî Meselesi" başlıklı makalesinde

\footnotetext{
38 Mesihlik iddiasında bulunarak en büyük mesihçilik hareketlerinden birini başlatan ve Müslüman olduktan sonra dönme cemaatini kuran bu Yahudi hakkında geniş bilgi için bk. Cengiz Şişman, "Sabatay Sevi”, TDV İslam Ansiklopedisi (DİA), XXXV, 334-335.

$39 \mathrm{Bu}$ makale Ali Duman tarafından sadeleştirilerek Hikmet Yurdu Dergisinde yayımlanmıştır. Bkz. Ali Duman, "Mehdî Meselesi", Hikmet Yurdu, 3/3-6 (2010): 339 346.
}

\begin{tabular}{|ccc} 
Kelâm Araştırmaları Dergisi & C.: 14, & S.: 1 \\
Journal of Kalâm Researches & V.: 14, & I.: 1 \\
[KADER-e-ISSN: 1309-2030] & 2016
\end{tabular}


mehdî hakkındaki görüşlerini kaydetmiştir. Makalenin başında verdiği bilgilerden anlaşıldığına göre, bu meseleye Muallim Atâ Efendi'nin kendisine sorduğu sorulardan üçüncüsüne cevap olarak değinmektedir. Buna göre soru şu şekilde sorulmuştur: "Mehdî hakkında hakikat nedir?" İzmirli bu soruya, mehdîlik fikrinin her asırda Müslümanlar arasında yaygın ve meşhûr olduğunu belirterek ve mehdîlik hakkında ana hatlarıyla bilgi vererek cevap vermeye başlar ve bu konuyla ilgili mülâhazalarını detaylı bir şekilde aktarır. ${ }^{40}$

İzmirli, mehdînin çıkışının İmâmiyye, sûfiyye ve ehl-i hadis tarafından savunulduğunu, ancak hem İmâmiyye'nin hem de Sûfiyye'nin ilk dönemlerinde böyle bir inancın bulunmadığını, bunun daha sonra söz konusu çevrelerin müteahhirîn dönemlerindeki mensupları tarafından yaygin hale getirildiğini, hattâ her iki zümre için ilerleyen zamanlarda bu konunun aslî bir mesele hüviyetine kavuştuğunu kaydetmektedir. Buna karşılık, ümmetin bir kısım âlimleri, kounyla ilgili rivâyetleri cerhederek, ulûmü'l-hadis kurallarına göre reddetmişlerdir. Müellife göre bütün bunlar dikkate alındığında, Mehdîlik hakkında beş görüss bulunduğu söylenebilir: 1. Mehdî, Hz. Ali'nin oğlu Hz. Hasan'ın evlâtlarındadır. 2. Mehdî, Hz. Ali'nin oğlu Hz. Hüseyin'in evlâtlarındadır. 3. Mehdî, Hz. Abbâs'ın evlâtlarındadır. 4. Mehdî, Hz. İsâ'dır. 5. Her sâlih insan veya her sâlih emîr, mehdîdir. ${ }^{41}$ İzmirli bunları belirttikten sonra, mehdînin zuhûrunu aklî ve naklî delilleri itibariyle değerlendirerek, bu hususta kanıt olarak ileri sürülen rivâyetleri, hem tek tek hem de genel olarak tenkid eder.

İzmirli, mehdî meselesini, öncelikle mâhiyeti açısından ele alır ve bunun gelecekle ilgili haberler (ahbâr-ı müstakbele) cümlesinden olduğunu, dolayısıyla onun zuhûr edebileceğinin aklen mümkün olduğunu belirtir. Daha sonra, bunun hem aklen hem âdeten hem imkân-1 zâtî hem de imkân-1 hissî açsından mümkün olduğunu ifade eder. ${ }^{42}$ İzmirli'nin bu yaklaşımı, onun meseleye aslâ ön yargılı yaklaşmadığını ve dinî bir meseleyi değerlendirmek için, bu alanda en elverişli yöntem hangisi ise onu benimsediğini göstermesi açısından önemlidir.

İzmirli'nin yöntemine göre -bu yöntem kelâmclların yöntemidir- bir konuda tam bir kanaate varmak için, aklî ya da naklî açıdan hiçbir şüpheye yer bırakmayacak derecede kesin bir bilginin olması gerekmektedir. Mehdîlik konusu, aklen vacip ya da muhâl (imkânsız) olan konulardan değildir. Başka bir ifadeyle mehdînin çıkışı aklen mümkündür. Ancak Mehdîlik konusu, geleceğe ait bir konu olduğundan, bunun sübûtü sadece haber ile mümkün olabilir. Dolayısıyla konu etrafında fikir yürütmemizi sağlayacak

\footnotetext{
40 İzmirli İsmail Hakkı, "Mehdi Meselesi”, Sebîlürreşâd Mecmûası, 33/285 (13 Şubat 1329 / 30 Rebîülevvel 1332), s. 389.

41 İzmirli, “Mehdi Meselesi”, s. 389b.

42 İzmirli, "Mehdi Meselesi”, s. 390.
}

\begin{tabular}{|c|c|c|}
\hline elŷm Araştırmaları & $\begin{array}{l}\text { Kelâm Araştırmaları Dergisi } \\
\text { Journal of Kalâm Researches } \\
\text { [KADER-e-ISSN: 1309-2030] }\end{array}$ & 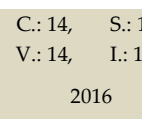 \\
\hline
\end{tabular}


tek kaynak haberdir. Haberin bağlayıcı olması ve tam bir kanaate vardırması için ise teknik tâbirle onun: "delâlet ve sübut açısından katî olması" şartını taşıması gerekmektedir. Makalenin ilerleyen kısımlarında Mehdîlik için dayanak olarak kabul edilen rivâyetleri tek tek ele alan müellif, bunları tenkit eder, onların bilgi değerlerini ortaya koymaya çalışır.

İzmirli, Mehdîlik hakkında rivâyet edilen haberleri değerlendirmeden önce, Hızır hakkındaki haberler gibi, bunların tamamının da hadisçiler tarafından tenkit edildiğini ve yine tamamının zayıf olduğunun anlaşıldığını kaydetmektedir. Buna bağlı olarak, bu rivâyetlere dayanarak mehdînin çıkışını iddia etmenin sağlam bir dayanağının bulunmadığına dikkat çeker. Bunu yaparken, ilgili alanın mütehassısları olan müelliflerle bunların kaleme aldığ1 literatüre referanslarda bulunur. Bunlar arasından İbn Hacer elAskalânî (ö. 852/1449), Şemseddin es-Sehâvî (ö. 902/1497), Abdurrahman elYemânî'nin (1894-1966) eserleriyle bunlardan derlenen Esna'l-Metâlib isimli eseri özellikle anar. Bu eserde, söz konusu hadislerden hiçbirinin 'şayân-1 itimâd' olmadığını kaydeder. Zayıf hadis, akâid, helâl ve haramlar konusunda belirleyici olmadığından, bu rivâyetlere dayanarak mehdînin çıkacağına inanmak mümkün değildir. ${ }^{43}$

İzmirli söz konusu rivâyetleri, hadisçilerin belirlediği kurallar doğrultusunda tenkid ettiğini, dolayısıyla bunu yaparken indî ve tartışmaya açık herhangi bir yöntemden yola çıkmadığını ifade ettikten sonra, bu hadisleri tek tek ele alarak onların niçin zayıf olduklarını belirler. Bu amaçla şu rivâyetleri ele alır:

Ebû Dâvûd ve Tirmizî'nin Âsım b. Ebü'n-Nücûd'un Zer rivâyeti,

Ebû Dâvûd'un Kutn b. Halife, Amr b. Ebû Kays rivâyetleri,

Ebû Dâvûd, İbn Mâce ve Hâkim'in Ali b. Nüfeyl rivâyeti,

Ebû Dâvûd ve Hâkim'in İmrân el-Kattân rivâyeti,

Tirmizî ve İbn Mâce'nin Zeyd el-Ammî rivâyeti,

Hâkim'in Ebü's-Sıddık en-Nâcî, Ammâr ez-Zehebî ve İsmâil b. İbrahim rivâyetleri,

İbn Mâce'nin Yezîd b. Ebü'z-Ziyâd, Yâsîn el-Acelî, İkrime b. Ammâr, Ebû Kılâbe ve İbn Luhay'a rivâyetleri,

Taberânî'nin Abdah b. Luhay'a, Abdullah b. Ömer el-Ammî ve Müsennâ b. es-Sabah rivâyetleri,

Bezzâr ve Taberânî'nin Muhammed b. Mervân ve Dâvûd b. el-Mihber rivâyetleri,

Ebû Ya'lâ el-Mevsılî’nin Recâ b. Ebû Recâ rivâyeti,

$43 \quad$ Izmirli, “Mehdi Meselesi”, s. 390.

\begin{tabular}{|ccc} 
Kelâm Araştırmaları Dergisi & C.: 14, & S.: 1 \\
Journal of Kalâm Researches & V.: 14, & I.: 1 \\
[KADER-e-ISSN: 1309-2030] & 2016
\end{tabular}


İzmirli, muhaddislerin ele aldığı bu rivâyetlerin ravîleri hakkındaki değerlendirmelerini naklederek bunları reddeder. Daha sonra Buhârî ve Müslim'deki doğrudan Mehdîlik hakkında olmadığı halde, dolaylı olarak mehdîliğe işaret ettiği ileri sürülen rivâyetlerin, bu konuyla uzaktan veya yakından alâkalı olmadığını belirtir. Dolayısıyla İzmirli'ye göre bu rivâyetlerin tamamı merduttur ve bunlara dayanarak mehdîlik hakkında herhangi bir kanaate varmak mümkün değildir. ${ }^{4}$

İzmirli, Mehdîlik hakkında makalenin başında belirlediği beş görüşten ilk üçünü bu şekilde reddettikten sonra dördüncü görüş olan Hz. Îsâ'nın mehdîlği konusuna değinir. İbn Mâce'nin naklettiği "Îsâ b. Meryem'den başka mehdî yoktur" rivâyetinin zayıf olduğunu, dolayısıyla öyle bir rivâyetin de konuda herhangi bir kanaate varmak için yeterli olmadığını belirtir. ${ }^{45}$ Daha sonra Mehdîlik hakkında beşinci görüş olan, "her asırda mehdînin bulunabileceği" hususunu ele alır. Bunun bir islahât anlamında kullanıldığını, dolayısıyla konuya bu açıdan bakılması gerektiğini kaydeder. Nitekim İbn Ömer, Muhammed b. el-Hanefiyye'ye bu anlamda "mehdî" demiştir. Aynı şekilde Ömer b. Abdülazîz'e, Câfer es-Sâdık'a, Mûsa b. Talha'ya ve Medine'de zuhûr eden Muhammed b. Hasan'a da "mehdî" denilmiştir. $\mathrm{Bu}$ değerlendirmeye göre her asırda mehdînin bulunması mümkündür. ${ }^{46}$

İzmirli, mehdînin çıkışına delil olarak keşif ve ilhâm yöntemiyle elde edilen bilgilerin de ileri sürüldügünü, mütekaddimîn dönem sûfîlerinde keşif ve ilhâmın mûtemed bir yöntem olmadığını, bunun müteahhirîn dönem sûfîleri tarafından dayanak olarak kabul edildiğini ifade eder. Ancak mütekellimîn ve fukahâ nezdinde keşif ve ilhâmın herhangi bir bilgi değeri olmadığından, ona göre buna dayanarak mehdînin çıkışını iddia etmek mümkün değildir. ${ }^{47}$

İzmirli, sonuç olarak mehdînin zuhûrunu kabul etmenin ancak dört yöntemle mümkün olabileceğini belirtmektedir. Bu dört yöntem şunlardır: 1 . Zayıf hadisleri dayanak olarak kabul etmek, 2. Bu hadisleri sahih olarak kabul etmek, 3. Buhârî ve Müslim'in rivâyetlerini bu doğrultuda yorumlamak 4. Keşif ve ilhâmın sadece ilgili şahsı değil, başkasını da ilzâm ettiğini kabul etmek. Bu dört yöntemin dışında, mehdînin zuhûrunu kabul etmek mümkün değildir. Bu yöntemlerin zayıf olduğu ve bu konu için herhangi bir mesnet teşkil edemeyeceği izahtan vârestedir. ${ }^{48}$

İzmirli, "Mehdi Meselesi”, s. 391.

İzmirli, "Mehdi Meselesi", s. 391.

İzmirli, "Mehdi Meselesi", s. 391.

İzmirli, "Mehdi Meselesi", s. 391.

İzmirli, "Mehdi Meselesi", s. 391.

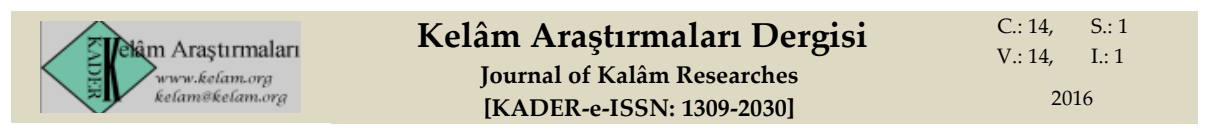


İzmirli, bu makalesini, işgale uğrayan Osmanlı topraklarında yaşayan Müslüman halkın, bu kriz durumundan kurtulmak için arayışlar içerisine girdiği bir dönemde kaleme almıştır. Halk, benzer diğer durumlarda olduğu gibi, mûcizevî bir şekilde kendilerine rehberlik ederek, sâhil-i selâmete götürecek bir kurtarıcı arayışına girmiş ve bu kurtarıcının mehdî olduğunu kabul etmiştir. İzmirli, dinî bir konu olan mehdîliği sistemli bir şekilde ve bilgi teorisinin verileri doğrultusunda değerlendirmeye tâbi tutmakta ve neticede bunun dinî dayanaklardan yoksun olduğu sonucuna varmaktadır. O, Hızır ile Mehdî arasında bir bağlantı kurarak Hızır'ın hayatı hakkında rivâyet edilen haberler nasıl eleştirilmiş ise, Mehdî'nin ortaya çıkışı hakkındaki hadislerin de eleştirildiğini belirtmektedir. İzmirli, konu etrafında bir değerlendirme yaptıktan sonra, neticede Mehdî ile ilgili olarak vârid olan haberlerin tenkide tâbi tutulduklarında, bunların tamamının zayıf çıktığını ifade etmektedir. Zayıf hadisler ise, üzerine herhangi bir düşünce ve kanaatin bina edilmesi açısından hiçbir şekilde yeterli ve kabul edilebilir değildir. Buna bağlı olarak mehdî inancının doğrudan kaynaklarımızdan alındığını kabul etmek de mümkün değildir.

\section{Mehmed Ali Takiyeddin, Mehdî, (Eskişehir 1339-1341/1923)}

Daha önce değinildiği üzere Osmanlı İmparatorluğu'nun duraklama döneminde de bir "kurtarıcı beklentisi" gündeme gelmiştir. Ancak Osmanlı İmparatorluğu"nun yıkıldığı ve Anadolu insanının ciddî bâdirelerden geçtiği süreçte de, hilâfetin Emevîler'den Abbasîler'e geçişi sürecinde olduğu gibi, Mehdîlik anlayışı yaygınlık kazanmıştır. Anadolu topraklarında siyasî iktidarla beraber dinin de elden gittiği kaygısına karşı, Kur'ân'ın öğrenilip okunması ve onun doğru anlaşılması için gayret sarf eden belirli zevât için "mehdî" tabiri kullanılmıştır. Bunların yanı sıra Anadolu'nun düşman işgalinden kurtarılması için mücadele eden ve TBMM'nin kurulması ve varlığını devam ettirmesinde öncülük yapan, Kurtuluş Savaşı'nın komutanı Mustafa Kemal başta olmak üzere, siyâseten iktidâr vaad eden zevât için de bu tâbirin zaman zaman kullanıldığı görülmektedir ${ }^{49}$.

İşte bu kriz ve sıkıntı durumunun aşılması için önerilerde bulunan şahsiyetlerden biri de Eskişehirli Mehmed Ali Takyeddin'dir. O, toplamda otuz dört varaktan oluşan Mehdî isimli risâlesinde ${ }^{50}$ memleketin çok ciddî bir süreçten geçtiğini, yıkım ve hezîmet dolu bu sürecin gerçek müsebbibinin padişahlık ve son Osmanlı padişahları olduğunu iddia etmektedir. Bundan kurtuluş yolunun, yönetimi ehil ellere teslim etmek olduğunu, bunun da Kurtuluş Savaşı'nın Başkomutanının önerisi doğrultusunda halkın seçtiği temsilcilerden oluşan bir meclise bağlı olduğunu ileri sürmektedir. Risâlesini iki kısma ayırarak birinci kısmında "emânet" metaforu üzerinden yönetimin ehline teslim edilmesi gerektiğinin dinî dayanaklarını; ikinci kısımda ise

49 Mehmed Ali Takiyeddin, Mehdî, (Eskişehir: 1923), s. 25.

50 Mehmed Ali Takiyeddin, Mehdî, s. 25.

\begin{tabular}{|c|c|c|}
\hline elâm Araştırmaları & $\begin{array}{l}\text { Kelâm Araştırmaları Dergisi } \\
\text { Journal of Kalâm Researches } \\
\text { [KADER-e-ISSN: 1309-2030] }\end{array}$ & $\begin{array}{c}\text { C.: } 14, \quad \text { S.: } 1 \\
\begin{array}{c}\text { V.: } 14, \quad \text { I.: } 1 \\
2016\end{array}\end{array}$ \\
\hline
\end{tabular}


"cihâd-1 ekber" metaforu üzerinden dâhilî problemlerimizin çözülmesi gerektiği üzerinde durmaktadır. İkinci kısımda, kendisinin de bir parçası olduğu toplumun, yaşanan krizi atlatması için yegâne kurtuluş umudu olan Mustafa Kemal'i "mehdî” olarak nitelemektedir.

Takiyeddin, tam da burada hiçbir teolojik tartışmaya girmeden doğrudan Mehdîlik inancına referansta bulunarak şunları ifade etmektedir: "Herkesin matlûbu olan bu gâyenin te'mînî esâsına mübtenîdir ki bugün hükûmetimizin şekl-i mârûz dâiresinde tersîn esâsinı kendilerinden nuhbe-i emel ittihâz eden dâhi-i âzâm ve Mehdî-i ümem "Gazî Mustafa Kemâl" Paşa Hazretlerinin riyâset-i zaîmâneleri altında teşekkül eden Anadolu ve Rûmeli Müdâfâ-i Hukuk grubunun vücûda getirmiş olduğu umdelerin dahî tefsîr ve teşrîhîyle bu risâlede kârilerime beyân etmeği dahi fâideden hâlî addetmiyorum". .51

Takiyededîn'in bu değerlendirmesi, Mehdîlik beklentisinin sosyo-politik bağlantılarını çarpıcı bir şekilde akla getirmektedir. Risâlenin tamamı değerlendirildiğinde, müellifin içerisinde bulunduğu siyasî ortam ve yaşanılan krizlerden etkilendiği ve onun bu krizlerden kurtuluş için çareler aradığı görülmektedir. Ona göre yaşanılan bu sıkıntıların aslî sebebi siyâsî idâredir. İdarenin başı olan Padişah ve onun etrafındaki kimseler, bu işe lâyık değil, hattâ derhal oradan uzaklaştırılması gereken şahsiyetlerdir. Risâlenin kaleme alındığı tarih dikkate alındığında, bunun saltanatın kaldırılmasından hemen sonra yazıldığı anlaşılmaktadır. Dolayısıyla müellif söz konusu uygulamanın halk tarafından benimsenmesi için elinden gelen gayreti sarf etmekte, bu amaçla Padişahın kâfir, zâlim ve hâin olduğunu belirtmekten çekinmemektedir. Aynı doğrultuda yeni oluşmakta olan siyasî durumun liderliğini tebcîl etmekte, bu oluşumun liderini "Mehdi-i ümem" olarak nitelemektedir. Söz konusu tasvirlerden, yeni durumun meşrûiyet zemîninin mehdîlik üzerinden oluşturulmaya çalışıldığı anlaşılmaktadır. Geçmiş dönemi değerlendirirken, dinî müesseselerin istismârı konusunda oldukça tenkitçi davranan müellif, yeni oluşuma sağlam bir zemin oluşturma konusunda dinî bir müessese olan mehdîlik üzerinden meşrûiyet

51 Takiyeddin, Mehdî, s. 25. Mehdîlik inancına sahip olan çevreler arasında bir takım ilginç tezadların yaşandığı, bazen aynı şahıs hakkında bir kısım çevreler "Mehdî" derken, başkaları "Deccâl" diyebilmiştir. Bu durum 1979 Kâbe Baskını'nı gerçekleştiren grubun lideri için de söz konusu olmuştur. Etrafındaki insanlar Muhammed b. Abdullah elKahtânî'nin "Mehdî" olduğunu düşündükleri halde, baskın esnasında Mescid-i Haram'da bulunan Muhammed Ali es-Sâbûnî başta olmak üzere başka çevreler de onun Deccâl olduğunu belirtmektedirler. Sâbûnî'nin ilgili ifadeleri aynen şöyledir: "Ben, Mehdîlik iddiasında bulunan (o şahsı) silahlı baskın yaptığını gördüğümde, onun Deccâl olduğunu anladım. $\mathrm{O}$ gün, ben de diğer namaz kılanlarla beraber Harem'deydim. Mehdî, Allah'tan bir rûh ile desteklenmekte, bombalar, tüfekler ve otomatik silahlarla değil, melekler ve müminler ile teyid edilmektedir." Bkz. Muhammed Ali es-Sâbûnî, el-Mehdî ve eşrâtü's-sââ, (Beyrut: 1981), s. 16. Geniş bilgi için bkz. Çınar, Mehdîlik, s. 221.

\begin{tabular}{|c|c|c|}
\hline elŷm Araştırmaları & $\begin{array}{l}\text { Kelâm Araştırmaları Dergisi } \\
\text { Journal of Kalâm Researches } \\
\text { [KADER-e-ISSN: 1309-2030] }\end{array}$ & $\begin{array}{cc}\text { C.: } 14, \quad \text { S.: } 1 \\
\text { V.: } 14, \quad \text { I.: } 1 \\
2016\end{array}$ \\
\hline
\end{tabular}


aramak suretiyle, bunu "istismâr etmekte" herhangi bir sakınca görmemektedir.

\section{Sonuç}

Osmanlı coğrafyasında yaşayan halklar, tasavvuf ile oldukça iç içe yaşamalarına rağmen, tasavvufun Sünnî dünyaya kattığı bir husus olan mehdîlik konusunda çok da fazla literatür oluşturmamışlardır. Kuşkusuz Mehdîlik düşüncesi, genel olarak Sünnî İslâm dünyasına Şîa üzerinden girmiştir. Ancak Osmanlı Müslüman halkları, daha çok Sünnî olduğu için, onlar bu düşünceyi tasavvuf üzerinden benimsemiştir. Tasavvufun bu konuda Şîa'dan etkilendiği hususu her türlü izahtan vârestedir. Osmanlı Müslüman halkının genel düşünce dünyasına uygun olarak, bu dönemde yazılan risâlelerde konu etrafında kayda geçirilenler, çoğu zaman elde mevcut bulunan bilgileri nakletmekten ibarettir. Mehdîliğin teorik çerçevesini temellendirme veya bu çerçeveye yeni unsurlar katan yorumlar oldukça azdır. Bu konuda Süyûtî, İbn Hacer el-Heytemî ve Aliyyü'l-Kârî gibi hadis âlimlerinin Mehdîlik hakkında yazdıklarının nakledilmesiyle yetinilmiştir. Bunu, Osmanlı Müslüman halkları açısından, siyaset alanında kitlesel buhrânların bulunmamasıyla açıklamamız mümkündür.

Çalışmamızda atıfta bulunulan örnekler dikkate alındığında, Osmanlı coğrafyasında Mehdîlikle bağlantılı olarak yapılan çalışmaların, siyasetin zayıfladığı dönemlerde arttığı görülmektedir. Ayrıca bu dönemlerde yapılan çalışmalarda nitelik açısından da farklılıklar bulunduğu, bu eserlerde teorik tartışmalara girildiği anlaşılmaktadır. Bu durum, mehdîliğin bir inanç veya teorik bir konu olmaktan çok, sosyo-psikolojik bir çözüm olduğu yönündeki yapılan değerlendirmeleri desteklemektedir. Osmanlıların yıkılışına denk gelen XX. yüzyılın başlarında bazılarının mehdî dediğini, bir başka grubun Deccâl olarak değerlendirmesi de, bu hususun sübjektif bir çözümleme olduğuna dâir başka bir kanıttır. Bu durum, tarihin diğer kesitlerinde olduğu gibi, Osmanlı Devleti Müslüman halkı içinde de Mehdîlik ve kurtarıcı beklentisinin sosyo-politik bir arayışın ürünü olduğuna işaret etmektedir.

Osmanlılar döneminde Mehdîlik etrafında yapılan çalışmalar sınırlı olmakla beraber, özellikle Naîmâ gibi, bu konuda oldukça orijinal çözümlemeler ortaya koyan müelliflerin telifâtı dikkate değerdir. Naîmâ'nın yaptığ değerlendirmeler, Duraklama devrine girmiş bulunan Osmanlı yönetimini kurtarmaya yönelik arayışlara ışık tuttuğu gibi, bir bütün olarak siyasî krizlerden kurtuluşun yöntemlerini de vermektedir. $\mathrm{Bu}$ yönüyle değerlendirildiğinde, söz konusu dönemde az da olsa bazı orijinal metinlerin ortaya konulduğunu kabul etmek gerekmektedir. Naîmâ'nın yaşadığı dönemde Bâb-1 Âli'de görülen siyasi zâflar onu bu arayışlara sevk etmiştir. Son dönemde için örnek verilen müelliflerden İzmirli İsmail Hakkı, teolojik bir konuyu usulüne uygun bir şekilde kaleme almıştır. İlgili iddialara mesned olarak sunulan bütün verileri almış ve bunları tek tek

\begin{tabular}{|c|c|c|}
\hline elâm Araştırmaları & $\begin{array}{l}\text { Kelâm Araştırmaları Dergisi } \\
\text { Journal of Kalâm Researches } \\
\text { [KADER-e-ISSN: 1309-2030] }\end{array}$ & $\begin{array}{c}\text { C.: } 14, \quad \text { S.: } 1 \\
\begin{array}{c}\text { V.: } 14, \quad \text { I.: } 1 \\
2016\end{array}\end{array}$ \\
\hline
\end{tabular}


inceleyerek, delil olamayacaklarını kanıtlamıştır. M. Ali Takiyedd3in ise, teolojik hiçbir sağlam kaynağa dayanmadan tamamen politik bir durumu meşrulaştırma adına bu teoriye başvurmuş, ilmî hiçbir değeri olmayan değerlendirmelerde bulunmuştur. Onun bu tavrı, Mehdîlik ve kurtarıcı beklentilerinin tarihî seyri dikkate alındığında, tipik bir yaklaşımdır. Zira bu söz konusu beklentiler, tarihin hiçbir döneminde siyasî ve sosyal uzatılarından bağımsız olarak gelişmemiştir. 


\section{Kaynakça}

Aksarâyî, Kerîmüddîn, Müsâmeretü'l-Ahbâr, haz. Osman Turan, Ankara: TTK Yayını, 1944.

Arslantürk, Zeki, Naîmâ'ya Göre XVII. Yüzyıl Osmanlı Toplum Yapısı, İstanbul: Ayışı̆̆ Kitapları, 1997.

Coşkun, Ali, "Naîmâ'nın Din ve Cemiyet Görüşü", yüksek lisans tezi, Erciyes Üniversitesi Sosyal Bilimler Enstitüsü, 1990.

Coşkun, Ali, Osmanlı da Din Sosyolojisi, İstanbul: İz Yayıncılık, 2004.

Çınar, Mahmut, Tarihte ve Günümüzde Mehdîlik, İstanbul: Rağbet Yayınları, 2013.

Hadimi, Ahmed b. Abdullah, Risâle fi Meciyi'l-Mehdi, Adana İl Halk Kütüphanesi, nr. 1027, vr. 13b-174a.

İbn Haldûn, Mukaddime, çev. Zâkir Kadiri Ugan, İstanbul: MEB Basımevi, 1986 I-III.

İbnü'l-Arabî, Muhyiddîn, el-Fütûhâtü'l-Mekkiyye haz. Ahmed Şemseddîn, Beyrut: Darü'l-kütübi'l-ilmiyye, ts.

İpşirli, Mehmet, “Naîmâ", TDV İslâm Ansiklopedisi (DİA), XXXII, 317-318.

İzmirli İsmail Hakkı, "Mehdî Meselesi", Sebîlürreşâd Mecmûası, 33/285 (13 Şubat 1329 / 30 Rebiülevvel 1332), s. 389a-391b.

Mısrî Efendi, er-Risâle fíl-Mehdiyye, Süleymaniye Kütüphanesi: Tercüman Bölümü nr. 00456.

Naîmâ, Târih, İstabul, ts., I-VI.

Öztoprak, Fahrettin, "Balkan Türkleri ve Şeyh Bedrettin", http://www.academia.edu/7862652/BALKAN TÜRKLERI VE ȘEYH BEDRETTIN (Erişim: 15 Temmuz 2015).

Şa'rânî, Abdülvehhâb, el-Yevâkît ve'l-cevâhir fì beyâni akâidi'l-ekâbir, Beyrut: Dâr Sâder, 2003.

Sâbûnî, Muhammed Ali, el-Mehdî ve eşrâtü's-sââ, Beyrut: 1981.

Şişman, Cengiz, "Sabatay Sevi", TDV İslâm Ansiklopedisi (DIA), XXXV, 334335.

Takiyeddin, Mehmed Ali, Mehdî, Eskişehir: 1923.

Winter, Michael, "Onaltıncı Yüzyılda Şa'râni ve Mısır Toplumu", çev. Mahmut Çınar, Marmara Üniversitesi Illahiyat Fakültesi Dergisi [İstanbul Yüksek İslâm Enstitüsü Dergisi], 41/2 (2011): 275-296.




Yaniç, Sema, "XIV. Asrın İlk Yarısında Anadolu'da Mehdî Bekleme Temâyülü ve Timurtaş'ın Mehdiliği Meselesi", Selçuk Üniversitesi İlahiyat Fakültesi Dergisi, 33 (2010): 181-195.

Yuvalı, Abdülkadir, "İlhanlılar", TDV İslâm Ansiklopedisi (DIA), XXII, 102105.

Yuvalı, Abdülkadir, "Ebû Said Bahadır Han", TDV İslâm Ansiklopedisi (DİA), X, 218-219.

\section{Müellifi Bilinmeyen Yazma Risâleler:}

Mehdi Hakkında Bir Risâle, Süleymaniye ktp: Hacı Mahmûd Efendi, nr. 1930/2, vr. 20-29.

Âhir Zamanda Mehdî; Deccâl; Yecûc ve Mecûc Zuhûr Hakknda Risâle, Süleymaniye ktp: Zühdü Bey, nr. 96/2, vr. 89-92.

Risâle fi hurûci'l-mehdî, Süleymaniye ktp: Hacı Mahmûd Efendi, nr. 594-02, vr. 11-588.

Risâletü'l-Mehdîye, Süleymaniye ktp: Şehid Ali Paşa, nr. 2893-01.

Risâle fî nüzĥli Îsâ ve hurûci'l-Mehdî, Süleymaniye ktp: Ayasofya, nr. 4795-19.

\begin{tabular}{|c|c|c|}
\hline 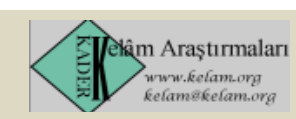 & $\begin{array}{l}\text { Kelâm Araştırmaları Dergisi } \\
\text { Journal of Kalâm Researches } \\
\text { [KADER-e-ISSN: 1309-2030] }\end{array}$ & 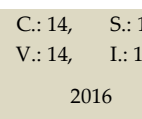 \\
\hline
\end{tabular}

